\title{
GNEISSES FROM THE GRANULITE TERRANE OF THE CENTRAL BOOTHIA UPLIFT, ARCTIC CANADA
}

\author{
VASSILY I. KITSUL ${ }^{1}$ \\ Institute of Geosciences, Siberian Division of the Russian Academy of Science, ul. Lenina 39, Yakutsk, 677891, Russia
}

VICTOR A. GLEBOVITSKY AND YEVGENY A. VAPNIK²

Institute of Precambrian Geology and Geochronology of the Russian Academy of Sciences, nab. Makarova 2, St. Petersburg, 199034, Russia

THOMAS FRISCH ${ }^{3}$

Geological Survey of Canada, 601 Booth Street, Ottawa, Ontario K1A OE8, Canada

\begin{abstract}
Orthopyroxene-bearing granitic (s.l.) gneiss and metamafic rocks and garnet-sillimanite paragneiss, which underwent granulite-facies metamorphism and intrusion by syenitic magma $1.9 \mathrm{Ga}$ ago, constitute the bulk of the highly deformed crystalline core of the Boothia Uplift. The sample suite investigated is representative of the central part of the uplift, exposed in northern Boothia Peninsula and southern Somerset Island. Two types of fluid inclusions predominate in quartz of the gneisses: $\mathrm{CO}_{2}$ with admixed methane or nitrogen, and brine. Temperatures and pressures calculated from garnet - orthopyroxene - plagioclase - quartz and garnet - sillimanite - plagioclase - quartz equilibria mostly fall in the ranges $740^{\circ}-850^{\circ} \mathrm{C}$ and $6-8 \mathrm{kbar}$. One sample of garnetorthopyroxene tonalite gneiss has preserved a record of what may be peak or near-peak conditions of metamorphism: $960^{\circ} \mathrm{C}$ and $8.7 \mathrm{kbar}$. Cordierite-bearing paragneisses yield $\leq 650^{\circ} \mathrm{C}$ and $<5 \mathrm{kbar}$, reflecting the retrograde formation of cordierite during decompression and cooling. The Boothia-Somerset granulite terrane probably represents an extension of the 1.9-2.0 Ga TaltsonThelon orogen, noted for its high-temperature metamorphism and magmatism, but is marked by a distinctive syntectonic intrusive suite and the presence of gneissic protoliths of earliest Proterozoic age.
\end{abstract}

Keywords: Boothia Uplift, geothermobarometry, metamorphism, granulite facies, fluid inclusions, Taltson-Thelon orogen, Canadian Arctic.

\section{SOMMAIRE}

Des gneiss granitiques (s.l.) à orthopyroxène, des roches métamafiques et des paragneiss à grenat-sillimanite, qui ont subi un métamorphisme au faciès granulite et l'intrusion d'un magma syénitique il y a $1.9 \mathrm{Ga}$, constituent la majorité des unités fortement déformées du socle cristallin de l'axe de soulèvement de Boothia, dans l'Arctique canadien. La collection d'échantillons étudiée est représentative de la partie centrale de la zone de soulèvement dans le secteur nord de la péninsule de Boothia et le sud de l'île de Somerset. Deux types d'inclusions fluides prédominent dans le quartz des gneiss: $\mathrm{CO}_{2}$ en mélange avec méthane ou azote, et saumure. La température et la pression calculées à partir des équilibres impliquant grenat - orthopyroxène - plagioclase - quartz and grenat - sillimanite - plagioclase - quartz mènent surtout aux intervalles $740^{\circ}-850^{\circ} \mathrm{C}$ et $6-8 \mathrm{kbar}$. Un échantillon de gneiss tonalitique à grenat-orthopyroxène contient des vestiges de ce qui pourrait être les conditions du paroxysme métamorphique: $960^{\circ} \mathrm{C}$ et $8.7 \mathrm{kbar}$. Des paragneiss à cordierite indiquent $\leq 650^{\circ} \mathrm{C}$ et $<5 \mathrm{kbar}$, témoignant ainsi d'une formation rétrograde de la cordierite pendant la décompression et le refroidissement. Le socle granulitique de Boothia-Somerset représenterait probablement l'extension de la ceinture orogénique de Taltson-Thelon (1.9-2.0 Ga), connue pour la température élevée du métamorphisme et du magmatisme, mais il s'en distingue par la présence d'une suite intrusive syntectonique et la présence d'un protolithe gneissique d'âge protérozoïque précoce.

(Traduit par la Rédaction)

Mots-clés: soulèvement de Boothia, géothermobarométrie, métamorphisme, faciès granulite, inclusions fluides, ceinture orogénique de Taltson-Thelon, Arctique canadien.

1 Present address: Koroleva 1.98, Stary Oskol, 309530, Russia.

2 Present address: Department of Geology and Mineralogy, Ben-Gurion University of the Negev, P.O. Box 653, 84105 Beer Sheva, Israel.

3 Corresponding author. E-mail address: thfrisch@nrcan.gc.ca 


\section{INTRODUCTION}

Boothia Peninsula extends northward from the central coast of northern mainland Canada and is separated by only a narrow strait from Somerset Island in the southern Arctic Archipelago. Much of northern Boothia Peninsula and western Somerset Island is underlain by granulite-facies metamorphic rocks of the Canadian Shield, and thus the Boothia-Somerset terrane provides a link between the high-grade tracts on the mainland to the south and in the High Arctic to the north.

In this paper, we describe a representative suite of gneisses from the Boothia-Somerset granulite belt, discuss the pressure-temperature conditions of their metamorphism, and draw comparisons with neighboring high-grade terranes.

\section{Geological Setting}

One of the major geological structures of the central Arctic of Canada is the Boothia Uplift, a >900 km-long, north-plunging welt stretching from southern Boothia Peninsula to northwestern Devon Island (Fig. 1). The southern two-thirds of the uplift comprises an $80-\mathrm{km}$ wide belt of Early Proterozoic and older(?) crystalline basement of the Churchill Structural Province flanked on the east and west by unmetamorphosed sedimentary rocks of Middle Proterozoic to Lower Devonian age. The Boothia Uplift formed mainly in Siluro-Devonian time (Okulitch et al. 1991), and the basement core was emplaced as a coherent block by westward thrusting in the Late Silurian (de Freitas \& Mayr 1993). These movements, of course, occurred long after cratonization of the crystalline rocks; little is known of the early history of the uplift.

The basement core of the Boothia Uplift is now exposed on Boothia Peninsula, western Somerset Island and easternmost Prince of Wales Island. Gneisses from the central part of the uplift, between $71^{\circ} \mathrm{N}$ and $74^{\circ} \mathrm{N}$ (Fig. 2), yield protolith ages ranging from $2.48 \mathrm{Ga}$ to ca. $2.2 \mathrm{Ga}$, based on $\mathrm{U}-\mathrm{Pb}$ zircon, and were affected by a major thermal event involving syenitic magmatism and granulite-facies metamorphism 1.94-1.92 Ga ago (Frisch \& Hunt 1993). This terrane is the source of the sample suite reported on here.

\section{Methods}

The samples analyzed in this study were collected by Kitsul and Glebovitsky while they were members of Frisch's field party during reconnaissance mapping of the Precambrian rocks of the central Boothia Uplift in 1986. Locations of the sampling traverses are plotted in Figure 2.

Chemical analyses of rocks by a combination of Xray fluorescence, atomic absorption and wet-chemical techniques and analyses of minerals with a Camebax electron microprobe were done by or under the supervi- sion of Kitsul at the Institute of Geosciences of the Russian Academy of Sciences, Yakutsk. Complete results of mineral analyses are available from the Depository of Unpublished Data, CISTI, National Research Council, Ottawa, Ontario K1A 0S2, Canada.

Fluid inclusions were investigated by Vapnik at the Institute of Precambrian Geology and Geochronology of the RAS, St. Petersburg. For microthermometric analyses, Vapnik used a microscope stage of his own design with a long-distance objective lens magnifying 32 times. The accuracy of measurements in the temperature range $-60^{\circ}$ to $+30^{\circ} \mathrm{C}$ is better than $0.5^{\circ}$.

Mineral abbreviations follow the recommendations of Kretz (1983).

\section{Lithology AND STRUCTURE}

The crystalline core of the Boothia Uplift consists essentially of north-trending, steeply dipping gneisses and supracrustal rocks, metamorphosed in the granulite facies and multiply deformed. In northern Boothia Peninsula and southern Somerset Island, the crystalline terrane is grossly divisible into a medial zone of granitic gneiss bordered by supracrustal rocks (Fig. 2), but intercalations of one rock type in the other, at a range of scales, are common. Concordant bodies of meta-intrusive rock, ranging from ultramafic to felsic in composition, occur sporadically.

The granitic (sensu lato) gneisses typically are moderately foliated, with a well-developed granoblasticpolygonal texture, but well-foliated, more strongly deformed varieties, with conspicuously platy quartz and mylonitic texture, are common. Two main types of gneiss occur. Predominant is a brown-weathering tonalitic to granodioritic gneiss, consisting of plagioclase, perthite, quartz, biotite, orthopyroxene and, locally, garnet; clinopyroxene may be an additional mineral in mafic varieties of gneiss. In highly sheared, retrograded gneiss, the K-feldspar is microcline, which, if abundant, imparts a pink color to its host. The other main type of gneiss occurs subordinately as pink, felsic intercalations, generally thin but locally up to several tens of meters thick, in the brown-weathering gneiss. It is rich in microcline and may contain garnet and biotitechlorite pseudomorphs of orthopyroxene. The leucocratic gneiss may represent originally intrusive rock but, if it does, intrusion must have been early and evidence for it has been lost, as contacts with the brown-weathering gneiss are highly concordant, and both types of gneiss have been deformed together. Migmatization of the brown gneiss is locally prominent and postdates emplacement of the pink gneiss. Narrow pegmatitic veins characteristically cross-cut the gneisses but may themselves be folded.

Supracrustal rocks include garnet-rich paragneisses, marble and calc-silicate rocks, quartzite and mafic gneisses. Supracrustal sequences are characterized by a layered, variegated appearance, predominantly with 

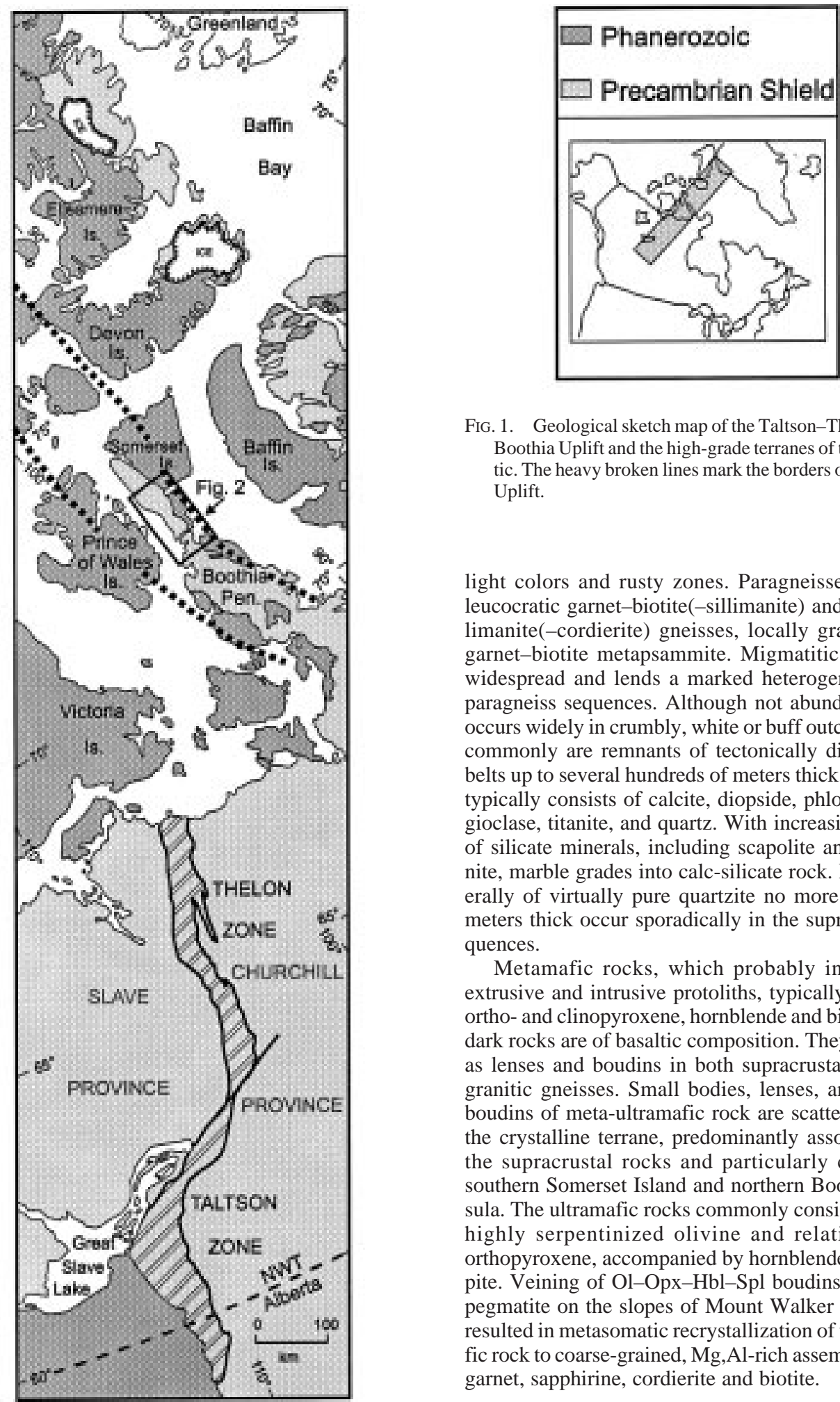

FIG. 1. Geological sketch map of the Taltson-Thelon orogen, Boothia Uplift and the high-grade terranes of the High Arctic. The heavy broken lines mark the borders of the Boothia Uplift.

light colors and rusty zones. Paragneisses comprise leucocratic garnet-biotite(-sillimanite) and garnet-sillimanite(-cordierite) gneisses, locally graphitic, and garnet-biotite metapsammite. Migmatitic layering is widespread and lends a marked heterogeneity to the paragneiss sequences. Although not abundant, marble occurs widely in crumbly, white or buff outcrops, which commonly are remnants of tectonically dismembered belts up to several hundreds of meters thick. The marble typically consists of calcite, diopside, phlogopite, plagioclase, titanite, and quartz. With increasing amounts of silicate minerals, including scapolite and wollastonite, marble grades into calc-silicate rock. Layers generally of virtually pure quartzite no more than a few meters thick occur sporadically in the supracrustal sequences.

Metamafic rocks, which probably include both extrusive and intrusive protoliths, typically carry both ortho- and clinopyroxene, hornblende and biotite. These dark rocks are of basaltic composition. They also occur as lenses and boudins in both supracrustal rocks and granitic gneisses. Small bodies, lenses, and trains of boudins of meta-ultramafic rock are scattered through the crystalline terrane, predominantly associated with the supracrustal rocks and particularly common in southern Somerset Island and northern Boothia Peninsula. The ultramafic rocks commonly consist largely of highly serpentinized olivine and relatively fresh orthopyroxene, accompanied by hornblende or phlogopite. Veining of Ol-Opx-Hbl-Spl boudins by granitic pegmatite on the slopes of Mount Walker (Fig. 2) has resulted in metasomatic recrystallization of the ultramafic rock to coarse-grained, $\mathrm{Mg}, \mathrm{Al}$-rich assemblages with garnet, sapphirine, cordierite and biotite. 


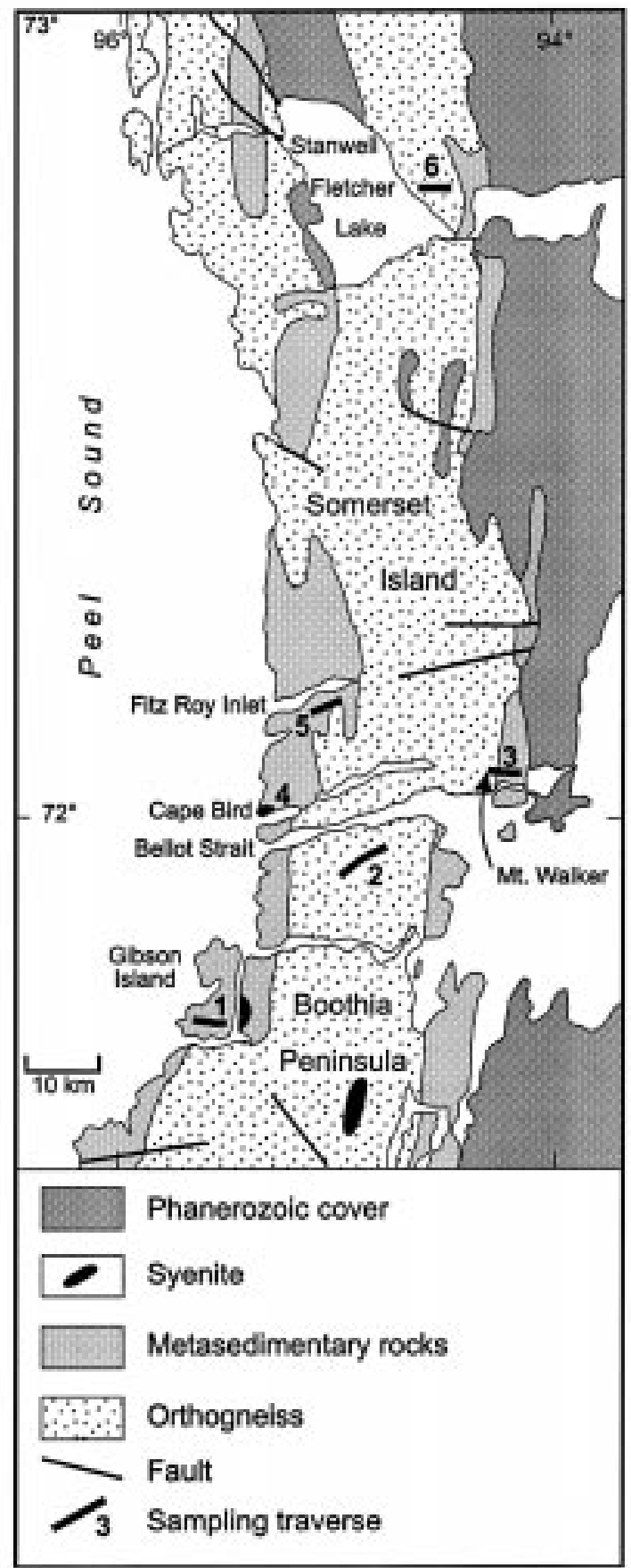

FIG. 2. Geological sketch map of northern Boothia Peninsula and southern Somerset Island.
Felsic intrusive rocks syntectonic with respect to the high-grade event, other than granite, which is confined to migmatite occurrences and pegmatite veins, are represented by two varieties of syenite. One variety, consisting of perthite, orthopyroxene, clinopyroxene, green hornblende, and minor quartz, forms a gneissic, concordant body, $3 \mathrm{~km}$ by $2 \mathrm{~km}$, at Cape Bird (Fig. 2). The other type of syenite (not sampled in this study) is a very felsic clinopyroxene-perthite rock, which occurs at three localities in northern Boothia Peninsula.

A post-tectonic body of massive, porphyritic rapakivi granite, dated at $1.71 \mathrm{Ga}$ (Frisch \& Hunt 1993), underlies an area $22 \mathrm{~km}$ long and up to $10 \mathrm{~km}$ wide at the northern end of the crystalline terrane on Somerset Island.

Mineral assemblages of rocks analyzed in this study are given in Table 1 .

Pervasive, upright north-south folding, with axes plunging moderately north and south, has produced the marked northerly structural "grain" of the crystalline core of the Boothia Uplift. This dominant phase of folding $\left(\mathrm{F}_{3}\right)$ was preceded by two other folding events, for the earlier of which $\left(\mathrm{F}_{1}\right)$ little evidence remains. However, interference between the second phase $\left(\mathrm{F}_{2}\right)$, an

TABLE 1. MINERAL ASSEMBLAGES, CENTRAL BOOTHIA UPLIFT

Sample Grt Opx Cpx Bt Hbl Crd Sil Pl Kfs QtzOpq*Spl Rt Tn

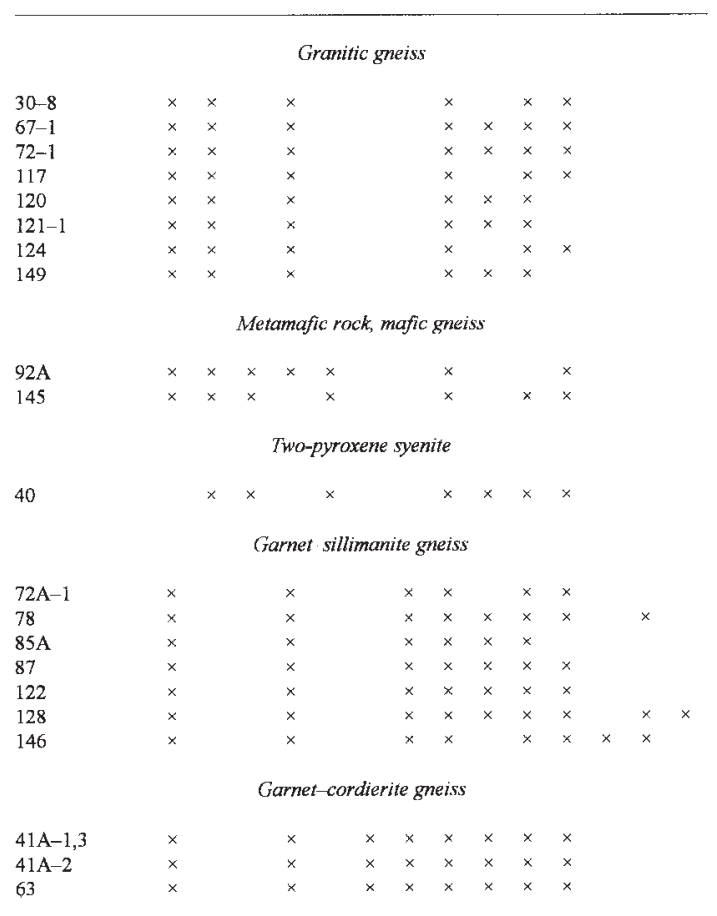


east-west, upright cross-folding, and $\mathrm{F}_{3}$ has resulted in prominent, kilometer-size domal or basinal structures. Clinopyroxene-perthite syenite occupies the core of three such structures. Mylonitization and flattening in north-trending ductile shear zones are widespread and particularly prominent at the margin of the Boothia Uplift in eastern Prince of Wales Island.

\section{Composition of The Rocks}

Twenty-three rocks were analyzed for major, minor and trace elements: seven orthopyroxene-bearing granitic gneisses, eight garnetiferous paragneisses, seven mafic and ultramafic rocks, and the two-pyroxene syenite.

Rocks judged to be meta-igneous approximate an igneous trend in the AFM diagram (Fig. 3). Mafic varieties follow an iron-enrichment path in the tholeiite field. The orthopyroxene-bearing granitic gneisses plot in the calc-alkaline field, trending toward alkali enrichment, possibly reflecting an intermediate to felsic igneous parentage.

In the paragneiss group, based on the relation between $\mathrm{Na}_{2} \mathrm{O} / \mathrm{K}_{2} \mathrm{O}$ and $\mathrm{SiO}_{2} / \mathrm{Al}_{2} \mathrm{O}_{3}$ (Rollinson 1993), garnet-sillimanite gneisses and garnet-biotite gneisses tend to fall in the greywacke and arenite-arkose fields, respectively.

\section{Composition of the Minerals}

The chemical characteristics of the ferromagnesian minerals, feldspars and selected accessory minerals analyzed with the electron probe are summarized below. Iron-to-magnesium ratios and plagioclase compositions critical for thermobarometry are listed in Tables 2-4.

Garnet in all but the mafic rocks belongs to the almandine-pyrope solid-solution series, with $\mathrm{Mn}$ and $\mathrm{Ca}$ rarely exceeding 0.1 atom per formula unit (apfu). Garnet of the granitic gneisses corresponds to the compositional range $(\mathrm{Alm}+\mathrm{Sps})_{57-72} \operatorname{Prp}_{20-37} \mathrm{Grs}_{3-9}$. In the paragneisses, garnet tends to be richer in the pyrope component, up to $55 \mathrm{~mol} \%$ Prp, and poorer in grossular. In mafic rocks, garnet occurs only in iron-rich varieties (bulk rock $\mathrm{Fe} / \mathrm{Mg} \geq 1.8$ ) and has a restricted compositional range: $(\mathrm{Alm}+\mathrm{Sps})_{65-68} \operatorname{Prp}_{10-15} \mathrm{Grs}_{20-22}$. The most magnesian garnet, with $X_{\mathrm{Mg}}[=\mathrm{Mg} /(\mathrm{Mg}+$ $\left.\mathrm{Fe}_{\mathrm{t}}\right)$ ] up to 0.68 , occurs in the metasomatic sapphirinebearing rocks bordering the ultramafic body on Mount Walker. Garnet grains are generally homogeneous except for local enrichment in iron at the margins, particu-

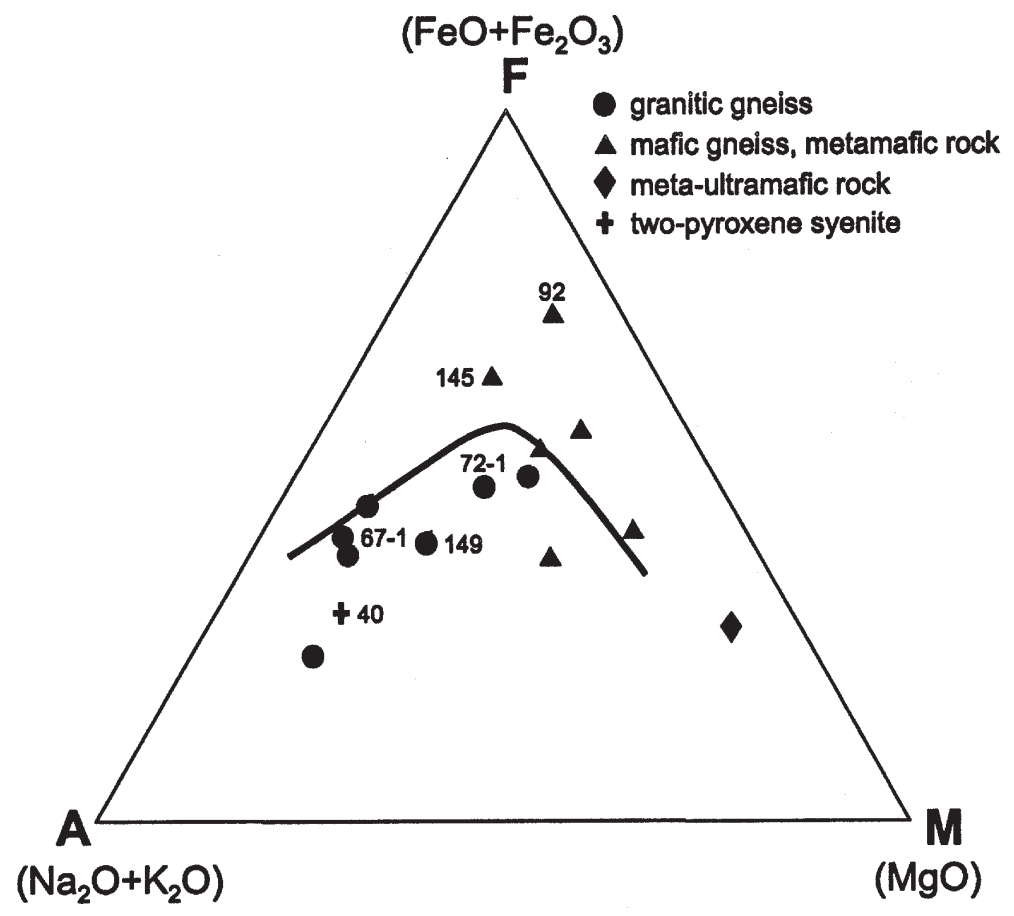

FIG. 3. AFM diagram of rocks from the crystalline core of the central Boothia Uplift. The heavy line is the Irvine-Baragar boundary between the calc-alkaline and tholeiitic fields (Rollinson 1993). Numbers refer to samples discussed in the text. 
TABLE 2. MINERAL COMPOSITIONS AND ESTIMATES OF TEMPERATURE AND PRESSURE OF METAMORPHISM OF ORTHOPYROXENE-BEARING ROCKS, CENTRAL BOOTHIA UPLIFT

\begin{tabular}{|c|c|c|c|c|c|c|c|c|c|c|c|c|c|}
\hline \multirow[t]{3}{*}{ Sample } & \multirow[t]{3}{*}{ Trav } & \multicolumn{3}{|c|}{$X_{\mathrm{Mg}}$} & \multirow{3}{*}{$\frac{X_{\text {An }}}{\mathrm{Pl}}$} & \multicolumn{6}{|c|}{ Temperature } & \multicolumn{2}{|c|}{ Pressure } \\
\hline & & \multirow[t]{2}{*}{ Git } & \multirow[t]{2}{*}{ Opx } & \multirow[t]{2}{*}{$\overline{\mathrm{Cpx}}$} & & \multicolumn{3}{|c|}{ Gt-Opx } & \multicolumn{2}{|c|}{$\mathrm{Grt}-\mathrm{Cpx}$} & \multirow{2}{*}{$\begin{array}{l}\overline{2 P X} \\
\overline{T P F}\end{array}$} & \multirow{2}{*}{$\begin{array}{c}\mathrm{GOPQ} \\
\overline{\mathrm{NP}}\end{array}$} & \multirow{2}{*}{$\begin{array}{r}\text { GCPQ } \\
\text { NP }\end{array}$} \\
\hline & & & & & & TPF & $\mathrm{AB}$ & SB & TPF & $\mathrm{EG}$ & & & \\
\hline $30-8$ & 3 & 0.374 & 0.605 & & 0.299 & 740 & 875 & 840 & & & & 5.8 & \\
\hline 40 & 4 & & 0.610 & 0.689 & 0.163 & & & & & & 770 & & \\
\hline $67-1$ & 5 & 0.232 & 0.446 & & 0.281 & 775 & 840 & 840 & & & & 6.7 & \\
\hline $72-1$ & 3 & 0.405 & 0.574 & & 0.346 & 960 & 930 & 1115 & & & & 8.7 & \\
\hline $92 \mathrm{~A}$ & 2 & 0.188 & 0.466 & 0.553 & 0.495 & 705 & & 690 & 745 & 770 & 750 & & \\
\hline 117 & 6 & 0.251 & 0.522 & & 0.272 & 675 & 750 & 690 & & & & 5.1 & \\
\hline 120 & 6 & 0.534 & 0.724 & & 0.245 & 810 & 900 & 910 & & & & 6.8 & \\
\hline $121-1$ & 3 & 0.410 & 0.618 & & 0.472 & 850 & 800 & 925 & & & & 6.9 & \\
\hline 124 & 3 & 0.256 & 0.491 & & 0.497 & 780 & 750 & 820 & & & & 6.3 & \\
\hline 145 & 4 & 0.174 & 0.396 & 0.549 & 0.518 & 780 & 780 & 815 & 740 & 770 & 665 & $6.5^{1}$ & $6.0^{2}$ \\
\hline 149 & 2 & 0.285 & 0.542 & & 0.377 & 740 & 720 & 760 & & & & 5.7 & \\
\hline
\end{tabular}

Sample numbers shown in bold refer to rocks that were chemically analyzed. Trav: sampling traverse (Fig. 2) Thermometers and barometers: 2PX: Opx-Cpx; GOPQ: Grt-Opx-Pl-Qtz; GCPQ: Grt-Cpx-Pl-Qtz; TPF: Fonarev et al. (1991); AB: Aranovich \& Berman (1997); SB: Sen \& Bhattacharya (1984); EG: Ellis \& Green (1979); NP: Newton \& Perkins (1982). ${ }^{1}$ Includes adjustment of -0.5 kbar (Newton 1983); ${ }^{2}$ includes adjustment of $+1.5 \mathrm{kbar}$ (Newton 1983).

larly where in contact with other ferromagnesian minerals.

Orthopyroxene is confined to the meta-igneous and the sapphirine-bearing rocks. $X_{\mathrm{Mg}}$ and weight percent $\mathrm{Al}_{2} \mathrm{O}_{3}$ ranges in orthopyroxene of the gneisses are 0.40 0.72 and $0.9-8.8$ (mostly $2-5$ ), respectively; in the mafic and ultramafic rocks, $X_{\mathrm{Mg}}$ attains 0.8 , but the $\mathrm{Al}$ content rarely exceeds 2 wt. $\% \mathrm{Al}_{2} \mathrm{O}_{3}$. Orthopyroxene coexisting with sapphirine has $X_{\mathrm{Mg}} \approx 0.8$ and 6-8\% $\mathrm{Al}_{2} \mathrm{O}_{3}$. Aluminum content correlates weakly with magnesium content. Typically, orthopyroxene grains are homogeneous, except for slight enrichment in iron in a narrow rim.

Clinopyroxene is found mainly in mafic-ultramafic and calc-silicate rocks and in the syenites, although in

TABLE 3. MINERAL COMPOSITIONS AND ESTIMATES OF TEMPERATURE AND PRESSURE OF METAMORPHISM OF GARNET-SILLIMANITE GNEISSES, CENTRAL BOOTHIA UPLIFT

\begin{tabular}{|c|c|c|c|c|c|c|}
\hline \multirow[t]{2}{*}{ Sample } & \multirow[t]{2}{*}{ Trav } & \multicolumn{2}{|c|}{$X_{\mathrm{Mg}}$} & \multirow{2}{*}{$\begin{array}{c}X_{\text {An }} \\
\mathbf{P l}\end{array}$} & \multirow{2}{*}{$\begin{array}{c}\mathrm{T}\left({ }^{\circ} \mathrm{C}\right) \\
\mathrm{TPF}\end{array}$} & \multirow{2}{*}{$\underset{\mathrm{KN}}{\mathrm{P} \text { (kbar) }}$} \\
\hline & & Grt & $\mathrm{Bt}$ & & & \\
\hline $72 \mathrm{~A}-1$ & 3 & 0.407 & 0.672 & 0.361 & 740 & 6.0 \\
\hline 78 & 3 & 0.495 & 0.763 & 0.266 & 710 & 4.9 \\
\hline $85 \mathrm{~A}$ & 3 & 0.550 & 0.787 & 0.185 & 740 & 6.7 \\
\hline 87 & 3 & 0.510 & 0.751 & 0.334 & 750 & 7.2 \\
\hline 122 & 3 & 0.459 & 0.680 & 0.244 & 795 & 7.8 \\
\hline 127 & 3 & 0.382 & 0.632 & 0.434 & 760 & 7.1 \\
\hline 128 & 3 & 0.388 & 0.625 & 0.267 & 780 & 6.9 \\
\hline 146 & 4 & 0.484 & 0.691 & 0.417 & 810 & 6.5 \\
\hline
\end{tabular}

Sample numbers shown in bold refer to rocks that were chemically analyzed. Trav: sampling traverse (Fig. 2). TPF: Grt-Bt thermometer of Fonarev et al. (1991); KN: Git-Sil-PI-Qtz barometer of Newton \& Haselton (1981), as corrected by Koziol \& Newton (1989). very minor amount in the clinopyroxene-perthite syenite. Clinopyroxene is uncommon in the granitic gneisses and, in this study, only one sample (145), a relatively mafic two-pyroxene gneiss, contains the requisite assemblage of clinopyroxene, garnet, plagioclase and quartz for application of garnet-clinopyroxene geobarometry. $X_{\mathrm{Mg}}$ of clinopyroxene is in the range $0.54-0.86$ in the mafic-ultramafic rocks, 0.55 in sample 145 , and 0.69 in the two-pyroxene syenite. The sodium content of the clinopyroxene is generally low, $<0.45$ wt. $\% \mathrm{Na}_{2} \mathrm{O}$, but reaches $0.95 \%$ in the two-pyroxene syenite. Some clinopyroxene shows minor zoning, grain rims being slightly richer in $\mathrm{Mg}$ than cores.

Amphibole is most common in rocks containing both ortho- and clinopyroxene, i.e., metamafic and meta-ul-

TABLE 4. MINERAL COMPOSITIONS AND ESTIMATES OF TEMPERATURE AND PRESSURE OF METAMORPHISM OF GARNET-CORDIERITE GNEISSES, CENTRAL BOOTHIA UPLIFT

\begin{tabular}{|c|c|c|c|c|c|c|c|c|c|c|}
\hline \multirow[t]{2}{*}{ Sample } & \multirow[t]{2}{*}{ Trav } & \multicolumn{3}{|c|}{$X_{\mathrm{Mg}}$} & \multirow{2}{*}{$\begin{array}{c}X_{\text {ant }} \\
\text { Pl }\end{array}$} & \multicolumn{3}{|c|}{$\begin{array}{c}\text { Temperature } \\
\left({ }^{\circ} \mathrm{C}\right)\end{array}$} & \multicolumn{2}{|c|}{$\begin{array}{c}\text { Pressure } \\
\text { (kbar) }\end{array}$} \\
\hline & & Grt & $\mathrm{Crd}$ & $\overline{\mathrm{Bt}}$ & & $\mathrm{AP}$ & $\mathrm{G}-\mathrm{C}$ & G-B & $\mathrm{AP}$ & $\mathrm{KN}$ \\
\hline $41 \mathrm{~A}$ & 1 & $0.319^{1}$ & 0.746 & & 0.316 & 748 & 740 & & 5.7 & 6.3 \\
\hline $41 \mathrm{~A}-1$ & 1 & $0.260^{2}$ & 0.746 & & & 658 & 640 & & 4.4 & \\
\hline $41 \mathrm{~A}-2$ & 1 & $0.271^{2}$ & $0.796^{2}$ & 0.650 & & 599 & 580 & 600 & 4.0 & \\
\hline $41 \mathrm{~A}-3$ & 1 & $0.246^{2}$ & $0.783^{2}$ & & & 585 & 570 & & 3.7 & \\
\hline $63-1$ & 5 & $0.362^{1}$ & 0.798 & 0.648 & 0.340 & 716 & 700 & 710 & 5.8 & 5.5 \\
\hline $63-3$ & 5 & $0.346^{2}$ & $0.826^{2}$ & & & 646 & 625 & & 5.1 & \\
\hline
\end{tabular}

Sample numbers shown in bold refer to rocks that were chemically analyzed. Trav: sampling traverse (Fig. 2). AP: Grt-Crd-Sil-Qtz thermobarometer of Aranovich \& Podlesskii (1989) for $\mathrm{CO}_{2}-\mathrm{Crd}$; $\mathrm{G}-\mathrm{C}$ and G-B: Grt-Crd and Grt-Bt temperatures recommended by Fonarev et al. (1991). KN: GSPQ barometer of Koziol \& Newton (1989). ${ }^{1}$ core, ${ }^{2}$ rim. 
tramafic rocks and the syenite at Cape Bird. All amphibole in the sample suite belongs to the calcic group and typically is olive-green to brown pargasite with a significant Ti content $\left(1.9-3.0 \% \mathrm{TiO}_{2}\right)$ and $(\mathrm{Na}+\mathrm{K})$ in the range 0.7-0.98 apfu. In two meta-ultramafic rocks, the amphibole is magnesiohornblende $\left(X_{\mathrm{Mg}}>0.8\right)$, with up to $1.6 \% \mathrm{TiO}_{2}$.

Biotite (here including phlogopite) occurs most abundantly in the paragneisses; it is common in the granitic gneisses and is typically minor in the metamafic rocks. $X_{\mathrm{Mg}}$ of biotite ranges from 0.6 to 0.8 the paragneisses, from 0.5 to 0.8 in the granitic gneisses, from 0.4 to 0.7 in the metamafic and meta-ultramafic rocks, and from 0.6 to 0.9 in the metasomatic sapphirine-bearing rocks. $X_{\mathrm{Mg}}$ correlates negatively with the amount of Al. The biotite is titaniferous (generally 4 $6 \% \mathrm{TiO}_{2}$ ) and may have significant $\mathrm{F}$ (exceeding $1 \%$ in several rocks and $2 \%$ in one of the sapphirine-bearing rocks). $X_{\mathrm{Mg}}$ correlates negatively with the amount of $\mathrm{Ti}$, and positively with the proportion of F. The most F-rich biotite is found in the sapphirine-bearing rocks; otherwise, there are no systematic variations in Ti and $\mathrm{F}$ contents in the biotite of the various rock types. Biotite included in or touching other ferromagnesian minerals, especially garnet, is invariably more magnesian than discrete biotite in the matrix. Such compositional variation is a common effect of diffusion-induced zoning in biotite during retrogression of high-grade rocks (Tracy 1982). Only compositions of isolated matrix biotite and garnet cores were used for geothermometric calculations.

Although nowhere abundant in the suite of rocks investigated, cordierite occurs in garnetiferous paragneisses and in the sapphirine-bearing rocks. The migmatitic cordierite-bearing gneisses are notably heterogeneous rocks, and mineral parageneses vary from place to place within a given sample (e.g., 41A, Tables 1,4$)$. Cordierite is consistently a late mineral, overgrowing needles of sillimanite and rimming grains of garnet and sapphirine. The cordierite rimming garnet is commonly intergrown with vermicular quartz; the cordierite rimming sapphirine at contacts with K-feldspar is symplectitically intergrown with orthopyroxene. The $X_{\mathrm{Mg}}$ value of cordierite in the paragneisses ranges from 0.74 to 0.84 ; the most magnesian cordierite occurs in direct contact with garnet and in symplectites. Cordierite in the sapphirine-bearing rocks tends to be more magnesian, $X_{\mathrm{Mg}}$ attaining 0.92 in cordierite-orthopyroxene symplectite.

Sapphirine in the Mount Walker occurrence forms prismatic grains mantled by a reaction rim of cordierite, which separates it from its associated minerals, orthopyroxene, biotite, garnet and feldspar; quartz is absent. Sapphirine has an $X_{\mathrm{Mg}}$ of 0.86 and contains 62 wt. $\% \mathrm{Al}_{2} \mathrm{O}_{3}$.

Plagioclase compositions range widely in orthopyroxene-bearing granitic gneisses, but mostly fall between 24 and $40 \mathrm{~mol} \%$ An. Typical ranges in other rocks are $\mathrm{An}_{24-36}$ in paragneisses, $\mathrm{An}_{44-58}$ in the metamafic rocks, and $\mathrm{An}_{16-23}$ in two-pyroxene syenite. Plagioclase grains in the gneisses are commonly antiperthitic. Zoning is rarely significant. Potassium feldspar typically takes the form of finely perthitic orthoclase (relatively coarse perthite in syenites), but in sheared rocks and in granitic veins, pink, cross-hatched microcline is characteristic.

Minerals of the spinel group are present in two samples of garnet-biotite(-sillimanite) gneiss and in a sapphirine-bearing ultramafic rock. The spinel of the gneisses is green hercynite with $0.30<X_{\mathrm{Mg}}<0.40$ and up to $5 \% \mathrm{ZnO}$; it has not been found in contact with quartz. Spinel sensu stricto is present in the ultramafic rock $\left(X_{\mathrm{Mg}}=0.645\right.$, up to $\left.5.8 \% \mathrm{Cr}_{2} \mathrm{O}_{3}\right)$.

\section{FLUID INCLUSIONS}

Fluid inclusions were investigated in seven samples of orthogneiss, five of paragneiss and two of metasomatic sapphirine-bearing rock. They were categorized as primary, secondary or pseudosecondary according to criteria outlined in other studies of fluid inclusions in metamorphic rocks (e.g., Roedder 1984, Janak et al. 1996).

Fluid inclusions in the Boothia-Somerset rocks are most common in quartz; they occur only rarely in garnet. In both minerals, the fluid inclusions tend to be distributed in linear zones and healed fractures that rarely cross-cut grain boundaries. Thus the inclusions are predominantly pseudosecondary, less commonly secondary and, locally, judged from their pattern of distribution, primary.

The majority of the fluid inclusions in the ortho- and paragneisses consist largely of carbon dioxide and are up to $10 \mu \mathrm{m}$ in size. They homogenize to the liquid between $-60^{\circ}$ and $+28^{\circ} \mathrm{C}$, but primarily between $-5^{\circ}$ and $+28^{\circ} \mathrm{C}$, and melt generally at $2-3^{\circ}$ below the melting point of pure $\mathrm{CO}_{2},-56.6^{\circ} \mathrm{C}$. The data attest to the presence of impurities in the carbon dioxide system, probably methane or nitrogen. In the absence of an identification by direct methods, such as Raman spectroscopy, we suggest methane as the likely contaminant because of its common occurrence in the $\mathrm{CO}_{2}$ system.

A limited number of inclusions have a homogenization temperature $\left(\mathrm{T}_{\mathrm{h}}\right)$ falling between $-80^{\circ}$ and $-110^{\circ} \mathrm{C}$. In only three cases was it possible to freeze the contents of an inclusion; melting temperatures $\left(\mathrm{T}_{\mathrm{m}}\right)$ were $-153^{\circ}$, $-100^{\circ}$ and $-91^{\circ} \mathrm{C}$. This type of inclusion is interpreted to be methane with up to 0.2 mole fraction $\mathrm{CO}_{2}$ (van den Kerkhof \& Thiery 1995).

Another relatively rare gaseous system is found in the larger $(>20 \mu \mathrm{m})$ inclusions. It homogenizes to the gaseous or, less commonly, the liquid phase at $-126^{\circ}$ to $-134^{\circ} \mathrm{C}$. These temperatures typify a nitrogen system with a small quantity of $\mathrm{CO}_{2}$. Commonly, in these inclusions, a bubble of $\mathrm{N}_{2}$ is surrounded by water.

Brine inclusions are common in quartz of ortho- and paragneisses, in distributions suggestive of both pseudo- 
secondary and secondary origin. They may in part be coeval with the carbonic inclusions, but we have no conclusive evidence as to the relative ages of the two types. Some brine inclusions contain halite crystals. First-melting temperatures $\left(\mathrm{T}_{\mathrm{mf}}\right)$ of ice in the brine inclusions suggest the presence of $\mathrm{CaCl}_{2}$-rich and $\mathrm{NaCl}$ rich solutions: the former have a $\mathrm{T}_{\mathrm{mf}}$ between $-70^{\circ}$ and $-49^{\circ} \mathrm{C}$, the latter have a $\mathrm{T}_{\mathrm{mf}}$ between $-30^{\circ}$ and $-20^{\circ} \mathrm{C}$. Salt concentrations are commonly in the range $2-40$ wt.\% equivalent $\mathrm{NaCl}$.

Although mixed $\mathrm{H}_{2} \mathrm{O}-\mathrm{CO}_{2}$ inclusions are uncommon, they do occur in zones where brine and $\mathrm{CO}_{2}$ inclusions developed concurrently. The $\mathrm{CO}_{2} / \mathrm{H}_{2} \mathrm{O}$ ratio varies, and the $\mathrm{CO}_{2}$ is of low density, with $\mathrm{T}_{\mathrm{h}}$ above $+20^{\circ} \mathrm{C}$.

Thus most of the fluid inclusions in our sample suite are either of the carbonic or brine type. The carbonic inclusions have varying admixtures of methane or nitrogen or both, typical of high-grade metamorphic rocks (Touret 1981). Microthermometry and Raman spectroscopy of fluid inclusions in rocks from north of Stanwell - Fletcher Lake (Fig. 2), performed at the United Institute of Geology, Geophysics and Mineralogy of the RAS in Novosibirsk, yielded broadly similar results (A.A. Tomilenko \& N.V. Popov, pers. commun., 1992).

The fluid inclusions in garnet of the sapphirine-bearing rocks from Mount Walker are of particular interest. They are predominantly pseudosecondary, with a few apparently primary, and consist of low-density $\mathrm{CO}_{2}$. $\mathrm{T}_{\mathrm{h}}$ ranges mainly from $+10^{\circ}$ to $+25^{\circ} \mathrm{C}, \mathrm{T}_{\mathrm{m}}$ from $-57.0^{\circ}$ to $59^{\circ} \mathrm{C}$. However, $\mathrm{CO}_{2}$ in the inclusions does not exceed $50 \%$ by volume, the remaining space being filled by a dark, coal-like phase. This phase requires positive identification but could be graphite. It is likely that these inclusions formed by the reaction $\mathrm{CH}_{4}+\mathrm{CO}_{2} \rightleftharpoons 2 \mathrm{C}+$ $2 \mathrm{H}_{2} \mathrm{O}$. The low density of the $\mathrm{CO}_{2}$ filling may reflect leakage of $\mathrm{H}_{2} \mathrm{O}$ from the inclusions (Bakker \& Jansen 1994).

Derivation of peak pressures of metamorphism from the fluid-inclusion data is not straightforward, in view of the complex composition of the inclusions and the wide range of homogenization temperatures. The densest $\mathrm{CO}_{2}$ inclusions, with $\mathrm{T}_{\mathrm{m}} \approx-56.6^{\circ} \mathrm{C}$ and $\mathrm{T}_{\mathrm{h}}$ greater than $-22.5^{\circ} \mathrm{C}$, formed at $6.7 \mathrm{kbar}$ at an assumed temperature of $800^{\circ} \mathrm{C}$. Monophase $\mathrm{CO}_{2}$ inclusions in garnet and quartz of garnet - orthopyroxene - cordierite gneisses near Stanwell-Fletcher Lake indicate a pressure of $6.0 \mathrm{kbar}$ at $850^{\circ} \mathrm{C}$ (A.A. Tomilenko \& N.V. Popov, pers. commun., 1992).

The broad range of densities of pseudosecondary and secondary carbonic inclusions is probably related to reequilibration during retrograde metamorphism, and typical of decompressional metamorphic regimes. The brine inclusions probably represent the aqueous component of the metamorphic fluid that, according to thermodynamic considerations (Hall \& Bodnar 1990), must have coexisted in equilibrium with $\mathrm{CO}_{2}-\mathrm{CH}_{4}$ fluids and likely promoted melting, migmatite formation and mass trans- fer under granulite-facies conditions. Mixed $\mathrm{H}_{2} \mathrm{O}-\mathrm{CO}_{2}$ inclusions are interpreted to have formed at the time of secondary redistribution of fluid in the crystals. Further work is needed to clarify the genesis of the methane and nitrogen inclusions.

\section{Mineral Thermobarometry}

Abundant analytical data indicate a regular distribution of $\mathrm{Fe}$ and $\mathrm{Mg}$ among coexisting minerals of the Boothia-Somerset suite of high-grade rocks. This suggested chemical equilibrium, together with apparent textural equilibrium (see above), invites application of geological thermometers and barometers to estimate temperatures and pressures of metamorphism. Mineral core compositions, each representing the average result of a substantial number of analyses of discrete grains not touching each other in the matrix, were used for most P-T calculations. In the case of garnet-cordierite gneisses, in which cordierite shows a reaction relationship to garnet, rim as well as core compositions were evaluated.

Three main mineral assemblages were used for thermobarometry: garnet - orthopyroxene - plagioclase - quartz (GOPQ) in granitic gneisses, and garnet - sillimanite - plagioclase - quartz (GSPQ) and garnet cordierite - sillimanite - quartz (GCSQ) in paragneisses. Temperatures and pressures were obtained with an updated version of the program TPF (Fonarev et al. 1991), which incorporates all the thermobarometric calibrations used here. For the GOPQ assemblage, two sets of temperatures derived from Grt-Opx equilibria were calculated: one is based on $\mathrm{Fe}-\mathrm{Mg}$ exchange (Graphchikov \& Fonarev 1990) and recommended by Fonarev et al. (1991), the other one is based on the solubility of $\mathrm{Al}$ in orthopyroxene (Aranovich \& Berman 1997). Pressures for the GOPQ assemblage were deduced from the reaction $\mathrm{Opx}+\mathrm{Pl} \rightleftharpoons \mathrm{Grt}+\mathrm{Qtz}$, as calibrated by Newton \& Perkins (1982). For the single sample (145) of garnetiferous quartzofeldspathic orthogneiss containing clinopyroxene in addition to orthopyroxene, analogous calibrations involving Cpx were applied (Fonarev et al. 1991, 1994, Newton \& Perkins 1982). The Grt-Cpx thermometer of Ellis \& Green (1979) was tested on sample 145 and on a quartz-free Grt-Opx-Cpx metamafic rock $(92 \mathrm{~A})$. In rocks containing ortho- and clinopyroxene, the two-pyroxene thermometer of Fonarev \& Graphchikov (1991) was evaluated. In paragneisses, for GSPQ, the TPF-recommended garnetbiotite thermometer and the geobarometer of Newton \& Haselton (1981), as corrected by Koziol \& Newton (1989), based on the reaction $\mathrm{Pl} \rightleftharpoons \mathrm{Grt}+\mathrm{Sil}+\mathrm{Qtz}$, were used. For the GCSQ assemblage, the calibration of Aranovich \& Podlesskii (1989) appropriate to $\mathrm{CO}_{2}$-rich cordierite (carbonic fluid inclusions being common in the paragneisses) provides temperature and pressure, simultaneously. 
Temperatures and pressures for the GOPQ and GSPQ assemblages agree fairly well, and most fall in the ranges $740^{\circ}-850^{\circ} \mathrm{C}$ and $6-8 \mathrm{kbar}$ (Tables 2,3 ). For the two-pyroxene gneiss (sample 145), temperature and pressure are $780^{\circ} \mathrm{C}$ and $7.0 \mathrm{kbar}$ for Grt-Opx, $740^{\circ} \mathrm{C}$ and $4.5 \mathrm{kbar}$ for Grt-Cpx. Empirical adjustment of pressures by subtracting 500 bars from the Grt-Opx value and adding 1500 bars to the Grt-Cpx value to compensate for uncertainties in $\Delta \mathrm{G}^{\circ}$ (Newton 1983) brings the two values of pressure into satisfactory alignment. Significantly lower values of temperature and pressure, $675^{\circ} \mathrm{C}, 5.1 \mathrm{kbar}$ (sample 117) and $710^{\circ} \mathrm{C}, 4.9 \mathrm{kbar}$ (sample 78), although derived from compositions of grain cores, suggest re-equilibration during cooling and uplift. Even lower temperatures and pressures, $<600^{\circ} \mathrm{C}$ and $<4 \mathrm{kbar}$, obtained from GCSQ assemblages, doubtless reflect the secondary formation of cordierite by reaction of garnet and sillimanite during cooling and decompression.

One sample (72-1 from Mount Walker) with the GOPQ assemblage gives temperature and pressure values higher than the remainder: $930^{\circ}-960^{\circ} \mathrm{C}$ and 8.7 kbar. From a study of reaction textures in sapphirine orthopyroxene(- garnet - kornerupine) assemblages in the ultramafic bodies on Mount Walker, Herd (1988) inferred maximum temperatures and pressures exceeding $800^{\circ} \mathrm{C}$ and $10 \mathrm{kbar}$. It seems, therefore, that sample 72-1 has fortuitously preserved a record of peak or nearpeak conditions of its metamorphism. Further indication that temperatures may once have been very high is provided by two other samples, which yield Al-in-Opx temperatures of $875^{\circ}$ and $900^{\circ} \mathrm{C}$ (Table 2). Lower temperatures and pressures obtained from other samples may reflect the limitations inherent in conventional thermobarometry applied to granulites (Frost \& Chacko 1989), i.e., re-equilibration during cooling and decompression.

The thermobarometric values obtained are plotted in Figure 4. Although some of the values may be spurious, owing to analytical or methodological problems, consistency in the results of several geothermometers and barometers applied to different assemblages in different lithologies corroborates the evidence from fluid inclusions and reaction textures that the Boothia-Somerset rocks followed a retrograde, decompressional $\mathrm{P}-\mathrm{T}$ path. Such paths are common in Proterozoic granulite terranes (Harley 1992).

\section{Comparisons with Neighboring TerRanes}

The Precambrian Shield terranes of southern Ellesmere and eastern Devon islands to the north and the Thelon Tectonic Zone on the mainland to the south (Fig. 1) are marked by high-grade metamorphism and magmatism at 1.9-2.0 Ga. The High Arctic terranes and the crystalline core of the Boothia Uplift may all belong to the Thelon Tectonic Zone or Thelon magmatic arc, as proposed by Hoffman (1989). It is of interest to compare the physical conditions of metamorphism in the Boothia-Somerset terrane with those determined in the north and south. In the case of garnet-pyroxene orthogneisses, the available data prescribe use of the Sen \& Bhattacharya (1984) Grt-Opx geothermometer and the Newton \& Perkins (1982) geobarometer for an internally consistent comparison. It should be noted that the Sen - Bhattacharya thermometer generally yields

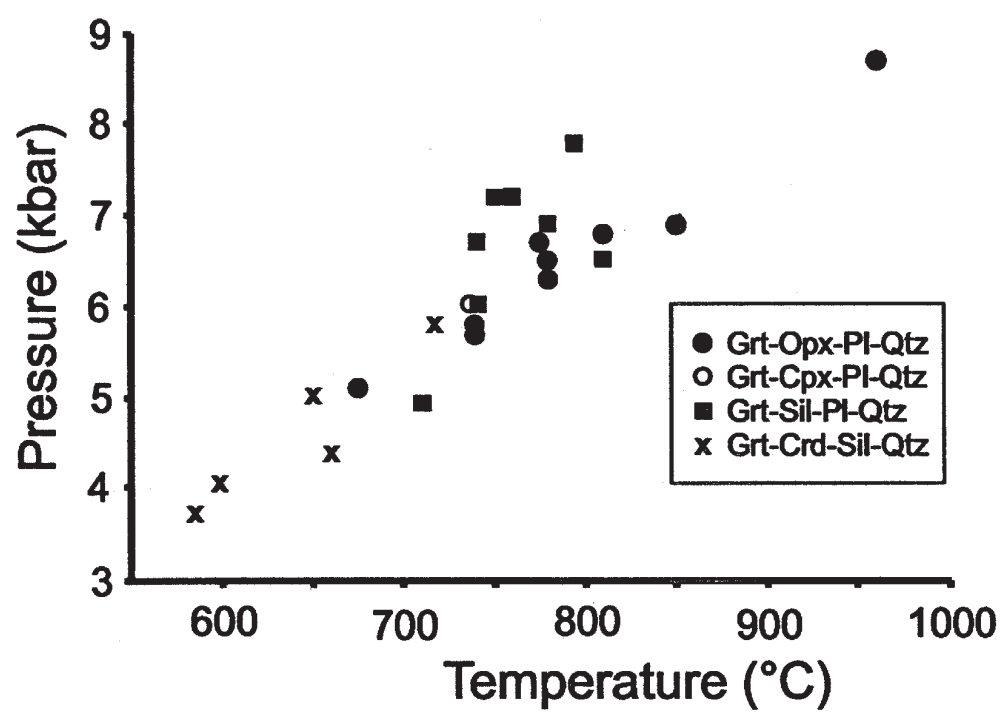

FIG. 4. Thermobarometry results for the crystalline core of the central Boothia Uplift. 
higher values than the TPF-recommended thermometer, but differences are typically on the order of only $40^{\circ}-$ $60^{\circ} \mathrm{C}$ (Table 2) and, except in the case of sample 72-1, never exceed $100^{\circ} \mathrm{C}$. On Ellesmere and Devon islands (Frisch 1988), compositions of mineral cores indicate a temperature range of $710^{\circ}-950^{\circ} \mathrm{C}$, with most samples showing $700^{\circ}<\mathrm{T}<800^{\circ} \mathrm{C}$, and a pressure range of 5.26.6 kbar. Paragneisses with the GSPQ assemblage give similar pressures, using the Newton \& Haselton (1981) geobarometer. Mineralogical features such as calcic mesoperthite in orthopyroxene granite on Ellesmere Island (Frisch 1988) and stably coexisting hercynite and quartz on Devon Island (T. Frisch, unpubl. data) provide further evidence of a temperature locally approaching $900^{\circ} \mathrm{C}$.

Thermobarometric data from the Thelon Tectonic Zone on the mainland southwest of the Boothia Uplift are available only from three narrow transects of the western margin of the zone (i.e., Slave-Churchill boundary). The first of these is in the area of Ragged Lake, immediately north of latitude $66^{\circ} \mathrm{N}$ (Thompson 1992), more than $700 \mathrm{~km}$ from Bellot Strait. The second transect lies at $64^{\circ} \mathrm{N}$ around Moraine Lake (James 1989), and the third a little farther south, at $63.5^{\circ} \mathrm{N}$, east of Artillery Lake (Haggart 1987). In the Ragged Lake area, temperatures and pressures within the Thelon zone are $894^{\circ} \mathrm{C}$ and $7.2 \mathrm{kbar}$ (average of three GOPQ samples) and ca. $7.7 \mathrm{kbar}$ (calculated at $900^{\circ} \mathrm{C}$ ) for one GCPQ sample (Thompson 1992). In the Moraine Lake transect, James (1989) estimated GOPQ temperature and pressure ranges of $615^{\circ}-812^{\circ} \mathrm{C}$ (average $690^{\circ} \mathrm{C}$ ) and 4.7-6.7 kbar (average 5.5 kbar); GSPQ assemblages yielded comparable values. James (1989) considered that temperatures derived from Grt-Opx thermometers were below peak values for the metamorphism, and calculated pressures at a $\mathrm{T}$ of $725^{\circ}$ or $775^{\circ} \mathrm{C}$. In the third transect, near Artillery Lake, maximum GOPQ temperature and pressure, from a single sample of a small dataset (Haggart 1987), are $900^{\circ} \mathrm{C}$ and $7.5 \mathrm{kbar}$; two other GOPQ rocks, which show signs of retrogression, give ca. $700^{\circ}-800^{\circ} \mathrm{C}$ and $5-6$ kbar.

Very high paleotemperatures have been recorded from the Taltson Magmatic Zone, which forms the extension of the Thelon zone south of approximately $63^{\circ} \mathrm{N}$ and is also earmarked by a high-grade thermal event between 1.9 and $2.0 \mathrm{Ga}$ (Chacko 1997, Grover et al. 1997, Berman \& Bostock 1997). In the northern Taltson zone, north of the Alberta-N.W.T. border, Berman \& Bostock (1997) obtained temperatures and pressures of $920^{\circ}-1045^{\circ} \mathrm{C}$ and $c a .7 \mathrm{kbar}$, based on Al-in-Opx thermometry. In the southern Taltson zone in northeastern Alberta, spinel + quartz associations, oxygen isotope thermometry and feldspar compositions of S-type granites and their metasedimentary enclaves indicate temperatures in excess of $850^{\circ} \mathrm{C}$, at pressures of 5-7 kbar (Chacko 1997, Farquhar et al. 1996, Grover et al. 1997). As Frisch (1988, p. 73) pointed out, the southern Taltson zone may find its counterpart in the granulite terrane of southern Ellesmere Island, where S-type granite with garnet, sillimanite, cordierite and spinel and abundant restitic, silica-deficient, metasedimentary enclaves abounds.

Undoubtedly, the granulite terranes of EllesmereDevon and Boothia-Somerset have important features in common: similar gneissic protoliths, including thick metasedimentary sequences, high-grade metamorphism and magmatism between 1.9 and $2.0 \mathrm{Ga}$, and decompressional paths of post-peak metamorphism. The Boothia-Somerset belt also resembles the TaltsonThelon zone in certain aspects. Yet there are significant differences in crustal architecture between segments of the Taltson - Thelon - Boothia-Somerset - DevonEllesmere belt of crystalline rocks. For example, the syntectonic felsic intrusive suite in the BoothiaSomerset belt is syenitic, with no known equivalents in the other terranes. Judged from the abundance of S-type granite plutons with metasedimentary relics, the degree of anatexis is much greater in Ellesmere Island and the Taltson zone than in the Boothia-Somerset belt, despite comparable temperatures of metamorphism. Berman \& Bostock (1997) concluded that metamorphic temperatures in the northern Taltson zone were higher than in the Thelon zone. Isotopic ages of orthogneiss protoliths vary along the Taltson-to-Ellesmere crystalline belt. A number of late Archean and >2.0 Ga Proterozoic ages ( $\mathrm{Nd}$ model and $\mathrm{U}-\mathrm{Pb}$ zircon) have been obtained from the Taltson zone (Bostock et al. 1991, Thériault 1992, Grover et al. 1997) and the Boothia-Somerset terrane (Frisch \& Hunt 1993). The Thelon zone has yielded only one Archean age, interpreted as the age of xenocrystic zircon in a 1.93-Ga-old granite, and few Proterozoic ages exceeding 2.0 Ga (Henderson \& Loveridge, 1990; Henderson \& van Breemen 1992). No age older than $2.14 \mathrm{Ga}$ has been recorded from Ellesmere Island (Hegner \& Jackson 1990). Although the high-grade terranes of Boothia-Somerset and Devon-Ellesmere probably comprise its northern extension, the TaltsonThelon orogen needs to be more precisely delimited north of the mainland, and the distribution of Archean and Proterozoic crust within it requires resolution. Achievement of those objectives would help in better understanding the nature of the Taltson-Thelon orogen and deciding between alternatives for its origin, such as a magmatic arc above a subduction zone in a collisional setting (Hoffman 1989) or an ensialic mobile belt developed within a plate well inboard of its margin (Thompson 1989, De et al. 1997).

\section{ACKNOWLEDGEMENTS}

This study was an outcome of the Canada - USSR Program of Scientific and Technical Cooperation in the Arctic and the North, specifically Theme 3.1, The geology of the ancient cores of platforms. Costs of the fieldwork in Canada were borne by the Geological Survey of Canada; invaluable logistical support was provided 
by the Polar Continental Shelf Project. We thank A.A. Graphchikov (Institute of Experimental Mineralogy, Chernogolovka) for provision of, and help with, the TPF program. K. Venance kindly made some thermobarometric calculations. D. Lemkow drew the figures. Critical reviews by L.Y. Aranovich, R.G. Berman and T. Chacko, and editorial comments by R.F. Martin, are greatly appreciated.

\section{REFERENCES}

Aranovich, L.Y. \& Berman, R.G. (1997): A new garnetorthopyroxene thermometer based on reversed $\mathrm{Al}_{2} \mathrm{O}_{3}$ solubility in $\mathrm{FeO}-\mathrm{Al}_{2} \mathrm{O}_{3}-\mathrm{SiO}_{2}$ orthopyroxene. Am. Mineral. 82, 345-353.

\& PodLESSKII, K.K. (1989): Geothermobarometry of high-grade metapelites: simultaneously operating reactions. In Evolution of Metamorphic Belts (J.S. Daly, R.A. Cliff \& B.W.D. Yardley, eds.). Geol. Soc., Spec. Publ. 43, 45-61.

BAKKER, R.J. \& JANSEN, J.B.H. (1994): A mechanism for preferential $\mathrm{H}_{2} \mathrm{O}$ leakage from fluid inclusions in quartz, based on TEM observations. Contrib. Mineral. Petrol. 116, 7-20.

Berman, R.G. \& Bostock, H.H. (1997): Metamorphism in the northern Taltson Magmatic Zone, Northwest Territories. Can. Mineral. 35, 1069-1091.

Bostock, H.H., VAN BReEMEN, O. \& Loveridge, W.D. (1991): Further geochronology of plutonic rocks in northern Taltson Magmatic Zone, District of Mackenzie, N.W.T. In Radiogenic Age and Isotopic Studies: Report 4. Geol. Surv. Can., Pap. 90-2, 67-78.

CHAско, T. (1997): Ultra-high temperature metamorphism at Pelican Rapids, Taltson magmatic zone, NE Alberta: possible implications for Early Proterozoic collisional orogens. Geol. Assoc. Can. - Mineral. Assoc. Can., Program Abstr. 22, A24.

De, S., Creaser, R., Chacko, T. \& Muehlenbachs, K. (1997): $\mathrm{Nd}, \mathrm{Pb}$ and $\mathrm{O}$ isotopic study of Taltson Magmatic Zone granites, NE Alberta: implications for the tectonic setting of the TMZ. Geol. Assoc. Can. - Mineral. Assoc. Can., Program Abstr. 22, A36.

De Freitas, T.A. \& MaYr, U. (1993): Middle Paleozoic tear faulting, basin development, and basement uplift, central Canadian Arctic. Can. J. Earth Sci. 30, 603-620.

ElLis, D.J. \& GReEN, D.H. (1979): An experimental study of the effect of $\mathrm{Ca}$ upon garnet-clinopyroxene $\mathrm{Fe}-\mathrm{Mg}$ exchange equilibria. Contrib. Mineral. Petrol. 71, 13-22.

Farquhar, J., Chacko, T. \& Ellis, D.J. (1996): Preservation of oxygen isotope compositions in granulites from Northwestern Canada and Enderby Land, Antarctica: implications for high-temperature isotopic thermometry. Contrib. Mineral. Petrol. 125, 213-224.
FonAREV, V.I. \& GRAPHCHIKOV, A.A. (1991): Two-pyroxene thermometry: a critical evaluation. In Progress in Metamorphic and Magmatic Petrology: a Memorial Volume in Honor of D.S. Korzhinskiy (L.L. Perchuk, ed.). Cambridge Univ. Press, Cambridge, U.K. (65-92).

\& Konilov, A.N. (1991): A consistent system of geothermometers for metamorphic complexes. Int. Geol. Rev. 33, 743-783.

$\&$

(1994): Experimental investigations of equilibria including minerals of variable composition and geological thermobarometry. In Experimental Problems in Geology. Nauka Press, Moscow, Russia (323$355)$.

FRISCH, T. (1988): Reconnaissance geology of the Precambrian Shield of Ellesmere, Devon and Coburg islands, Canadian Arctic Archipelago. Geol. Surv. Can., Mem. 409.

\& Hunt, P.A. (1993): Reconnaissance U-Pb geochronology of the crystalline core of the Boothia Uplift, District of Franklin, Northwest Territories. In Radiogenic Age and Isotopic Studies: Report 7. Geol. Surv. Can., Pap. 93-2, 3-22.

Frost, B.R. \& Chacko, T. (1989): The granulite uncertainty principle: limitations on thermobarometry in granulites. $J$. Geol. 97, 435-450.

Graphchikov, A.A. \& Fonarev, V.I. (1990): Garnet orthopyroxene - plagioclase equilibria and geobarometry: an experimental study. In Experiment-89 (V.A. Zharikov, ed.). Nauka Press, Moscow, Russia (34-37).

Grover, T.W., Pattison, D.R.M., McDonough, M.R. \& MCNicolL, V.J. (1997): Tectonometamorphic evolution of the southern Taltson Magmatic Zone and associated shear zones, northeastern Alberta. Can. Mineral. 35, 1051-1067.

Haggart, M.J. (1987): Geothermobarometry of the Slavel Churchill Structural Provinces Boundary, Artillery Lake Map Area, District of Mackenzie. B.Sc. thesis, Queen's Univ., Kingston, Ontario.

HaLl, D.L. \& BodnaR, R.J. (1990): Methane in fluid inclusions from granulites: a product of hydrogen diffusion? Geochim. Cosmochim. Acta 54, 641-651.

Harley, S.L. (1992): Proterozoic granulite terranes. In Proterozoic Crustal Evolution (K.C. Condie, ed.). Elsevier, New York, N.Y. (301-359).

Hegner, E. \& JACKSON, G.D. (1990): Nd isotopic constraints on late Archean and early Proterozoic crust formation in Baffin and Ellesmere islands, northern Labrador and Ungava Peninsula, eastern Canada. Trans. Am. Geophys. Union (Eos) 71, 1689 (abstr.).

Henderson, J.B. \& Loveridge, W.D. (1990): Inherited Archean zircon in the Proterozoic Thelon Tectonic Zone: $\mathrm{U}-\mathrm{Pb}$ geochronology of the Campbell granite, south of 
McDonald fault, District of Mackenzie, Northwest Territories. In Radiogenic Age and Isotopic Studies: Report 3. Geol. Surv. Can., Pap. 89-2, 63-70.

\& VAN BREEMEN, O. (1992): U-Pb zircon ages from an Archean orthogneiss and a Proterozoic metasedimentary gneiss of the Thelon Tectonic Zone, District of Mackenzie, Northwest Territories. In Radiogenic Age and Isotopic Studies: Report 5. Geol. Surv. Can., Pap. 91-2, 25-33.

HeRD, R.K. (1988): Sapphirine - hypersthene - garnet and sapphirine - kornerupine - hypersthene assemblages from Somerset Island, Northwest Territories, Canada, and their tectonic significance. Geol. Soc. Am., Abstr. Programs 20(7), A160.

Hoffman, P.F. (1989): Precambrian geology and tectonic history of North America. In The Geology of North America - an Overview (A.W. Bally \& A.R. Palmer, eds.). Geological Society of America, Boulder, Colorado (A: 447-512).

JAMES, D.T. (1989): Geology of the Thelon Tectonic Zone in the Moraine Lake Area, District of Mackenzie, Northwest Territories: the Definition and Significance of Lithologic, Structural and Metamorphic Changes Across the Boundary Between the Slave and Churchill Structural Provinces. Ph.D. thesis, Queen's Univ., Kingston, Ontario.

Janak, M., O'Brien, P.J., Hurai, V. \& Reutel, C. (1996): Metamorphic evolution and fluid composition of garnetclinopyroxene amphibolites from the Tatra Mountains, western Carpathians. Lithos 39, 57-79.

Koziol, A.M. \& Newton, R.C. (1989): Grossular activitycomposition relationships in ternary garnets determined by reversed, displaced phase equilibrium experiments. Contrib. Mineral. Petrol. 103, 423-433.

Kretz, R. (1983): Symbols for rock-forming minerals. Am. Mineral. 68, 277-279.

Newton, R.C. (1983): Geobarometry of high-grade metamorphic rocks. Am. J. Sci. 283-A, 1-28.

\& Haselton, H.T. (1981): Thermodynamics of the garnet - plagioclase $-\mathrm{Al}_{2} \mathrm{SiO}_{5}$ - quartz geobarometer. In Thermodynamics of Minerals and Melts (R.C. Newton, A. Navrotsky \& B.J. Wood, eds.). Springer-Verlag, New York, N.Y. (131-147).

\& PERKINS, D., III (1982): Thermodynamic calibration of geobarometers based on the assemblages garnet plagioclase - orthopyroxene (clinopyroxene) - quartz. Am. Mineral. 67, 203- 222.
OKulitch, A.V., PACKard, J.J. \& Zolnai, A.I. (1991): Late Silurian - Early Devonian deformation of the Boothia Uplift. In Geology of the Innuitian Orogen and Arctic Platform of Canada and Greenland (H.P. Trettin, ed.). Geol. Surv. Can., Geology of Canada 3, 302-307.

RoEdDER, E. (1984): Fluid Inclusions. Rev. Mineral. 12.

Rollinson, H.R. (1993): Using Geochemical Data: Evaluation, Presentation, Interpretation. Longman Scientific \& Technical, Harlow, U.K.

Sen, S.K. \& Bhattacharya, A. (1984): An orthopyroxenegarnet thermometer and its application to the Madras charnockites. Contrib. Mineral. Petrol. 88, 64-71.

ThÉRIAUlt, R.J. (1992): Nd isotopic evolution of the Taltson magmatic zone, Northwest Territories, Canada: insights into Early Proterozoic accretion along the western margin of the Churchill Province. J. Geol. 100, 465-475.

Thompson, D.L. (1992): Proterozoic Evolution of the Northern Thelon Tectonic Zone. Ph.D. diss., Princeton Univ., Princeton, New Jersey.

Thompson, P.H. (1989): An empirical model for metamorphic evolution of the Archaean Slave Province and adjacent Thelon Tectonic Zone, north-western Canadian Shield. In Evolution of Metamorphic Belts (J.S. Daly, R.A. Cliff \& B.W.D. Yardley, eds.). Geol. Soc., Spec. Publ. 43, 245263

TOURET, J. (1981): Fluid inclusions in high grade metamorphic rocks. In Fluid Inlusions: Applications to Petrology (L.S. Hollister \& M.L. Crawford, eds.). Mineral. Assoc. Can., Short Course Handbook 6, 182-208.

TRACY, R.J. (1982): Compositional zoning and inclusions in metamorphic minerals. In Characterization of Metamorphism through Mineral Equilibria (J.M. Ferry, ed.). Rev. Mineral. 10, 355-397.

Van Den Kerkhof, F. \& Thiery, R. (1995): Phase transitions and density calculation in the $\mathrm{CO}_{2}-\mathrm{CH}_{4}-\mathrm{N}_{2}$ system. In Fluid Inclusions in Minerals: Methods and Applications (2nd printing). Virginia Polytechnic and State University, Blacksburg, Virginia (171-190).

Received June 18, 1998, revised manuscript accepted November 17, 1999. 